Latvia University of Life Sciences and Technologies

Faculty of Agriculture

Institute of Soil and Plant Sciences

\title{
GENERAL PLANT PATHOLOGY: EXERCISES
}

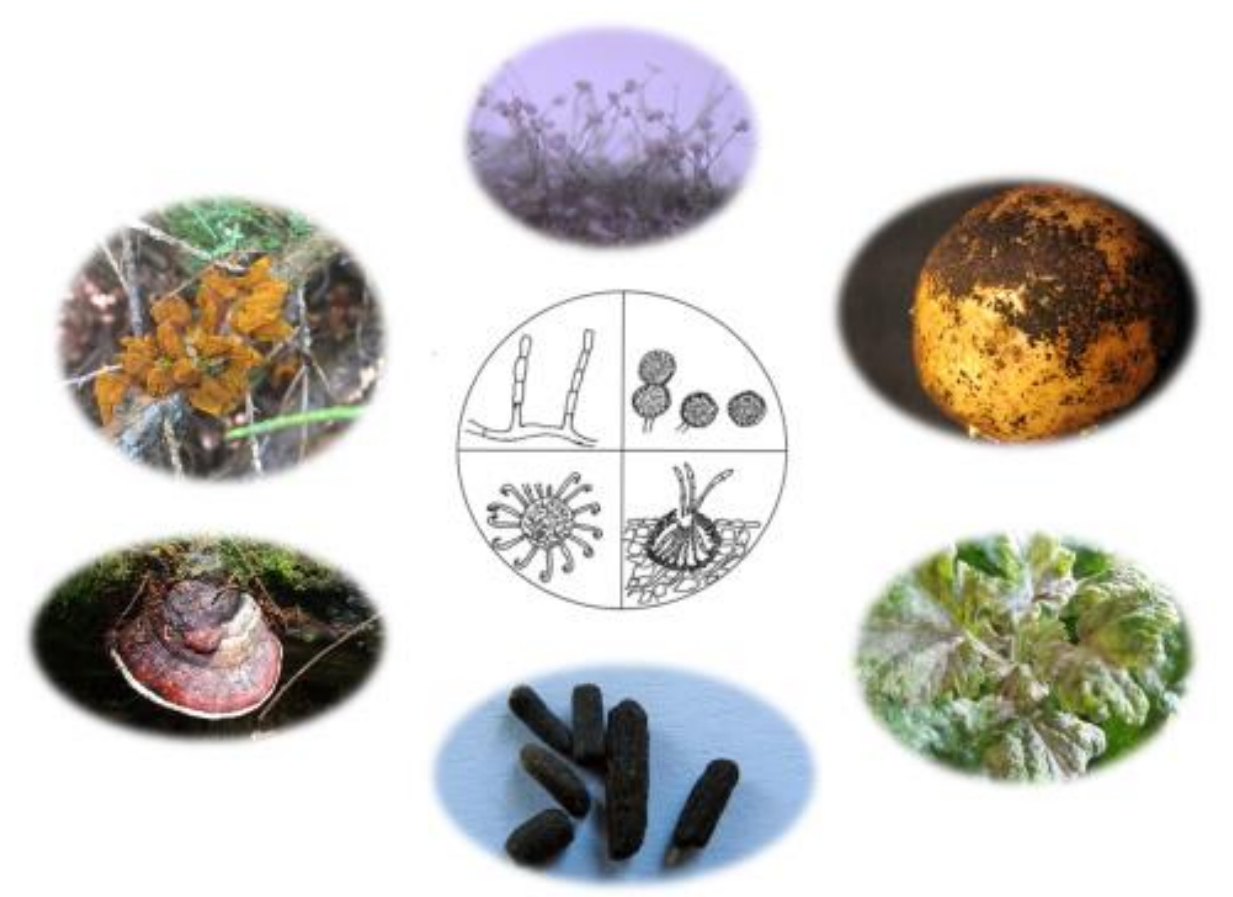

Biruta Bankina, Gunita Bimšteine, Jānis Kaṇeps

Jelgava 
Bankina B., Bimšteine G., Kaņeps J. (2021). General plant pathology: exercises. Jelgava: Latvia University of Life Sciences and Technologies. - 34 p.

This illustrated issue provides students with currently comprehensive information about organisms from the kingdoms of Fungi, Chromista, and Protozoa - important groups of plant pathogens. It covers characterisation of the composition and reproduction of fungi, as well as basic principles of their systematics. The most important orders of plant pathogenic fungi are described, and examples of important pathogens and the description of diseases are given.

Reviewers:

Vizma Nikolajeva, Dr. biol., Associate Professor, University of Latvia Diāna Meiere, Mg. biol., Latvian National Museum of Natural History

Language editor: Inga Skuja.

\section{ISBN 978-9984-48-381-8}

DOI: $10.22616 / 11 u 9789984483818$

This issue contains information obtained from authentic and highly accepted sources. The author of pictures: Gunita Bimšteine.

(C) B. Bankina, G. Bimšteine, J. Kaṇeps 


\section{CONTENT S}

1. THE CONCEPT OF PLANT DISEASES AND THEIR SYMPTOMS .............................

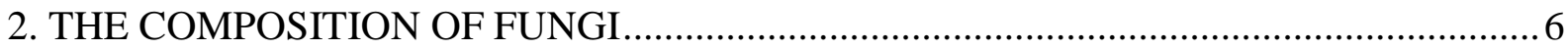

3. THE MAIN PRINCIPLES OF THE SYSTEMATICS OF FUNGI AND OTHER MICROORGANISMS - THE CAUSAL AGENTS OF PLANT DISEASES ........................ 10

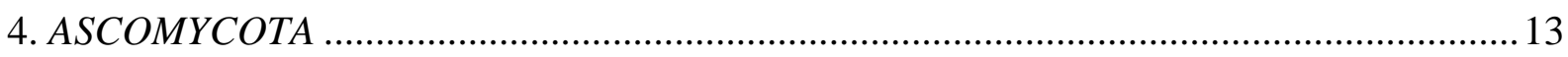

4.1. IMPORTANT ORDERS FROM THE PHYLUM ASCOMYCOTA............................ 15

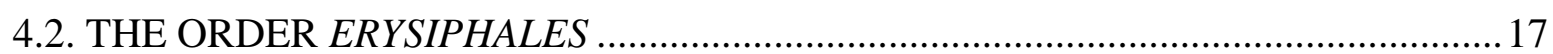

5. TRAITS OF ASEXUAL REPRODUCTION OF FUNGI FROM THE PHYLA

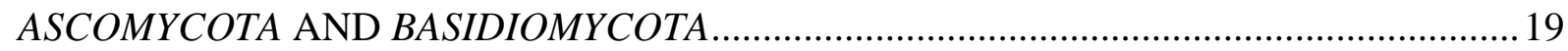

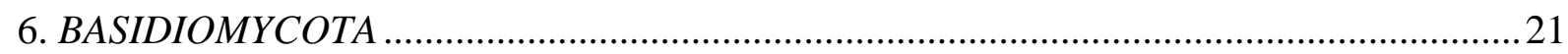

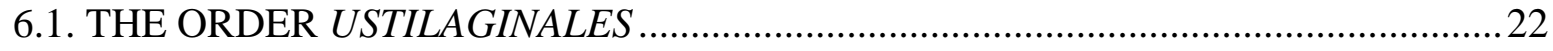

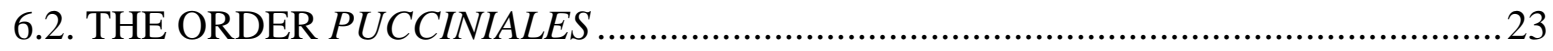

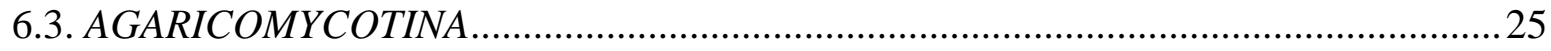

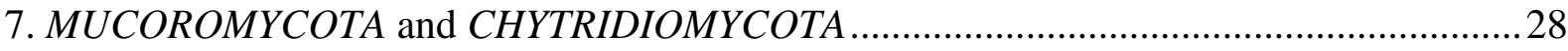

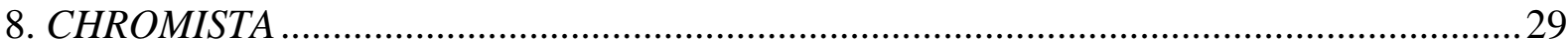

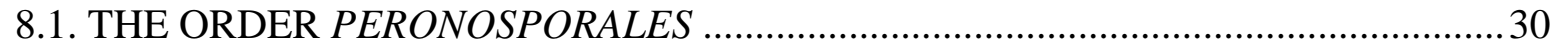

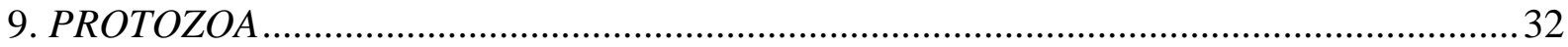

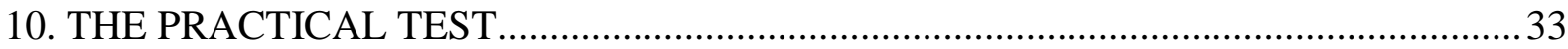

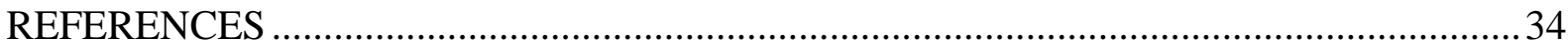




\section{THE CONCEPT OF PLANT DISEASES AND THEIR SYMPTOMS}

Plant disease is a deviation from normal plant growth and development, which can be caused by living organisms (fungi, viruses, etc.) and factors of inanimate nature, for example, lack or abundance of water.

Plant disease is a process that happens between a plant and a
pathogen if conditions of environment are favourable for the
development of a disease.

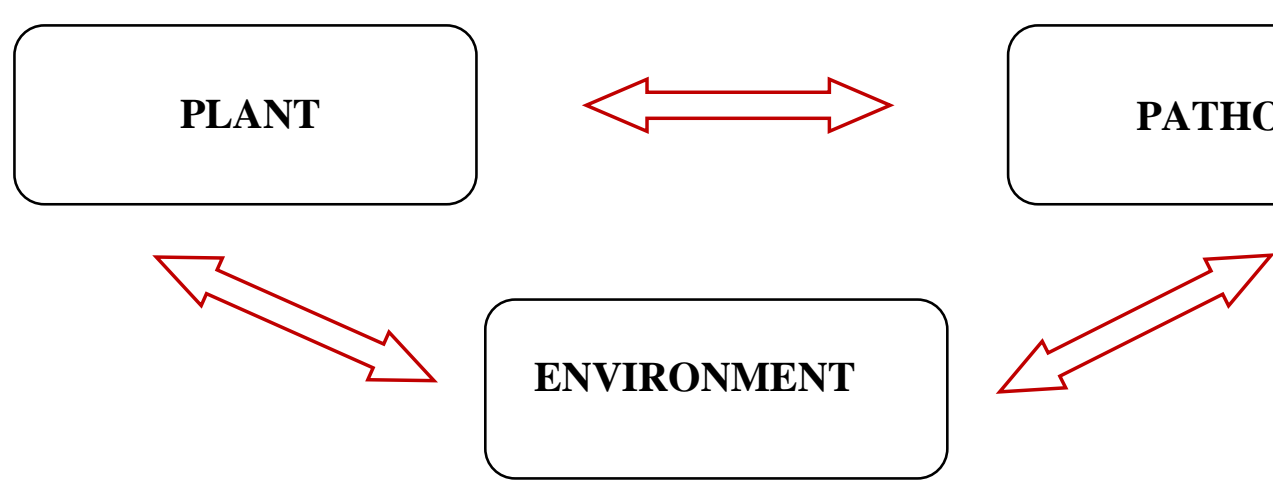

Plant pathogen is a living organism; it has a binominal name in the Latin language, which must be written in italics, for example, Heterobasidion annosum. Only some of pathogens have also a national name.

Viruses are an exception, which names are abbreviations from the English language and are not written in italics, for example, BYDV (barley yellow dwarf virus).

The name of disease is in English (or other national language). Sometimes, Latin name is part of the name of a disease, in which case it is not written in italics, for example, Septoria leaf blotch.

\section{Examples}

$\checkmark$ Root rot of spruce is caused by honey fungus.

$\checkmark$ Late leaf blight of potatoes is caused by Phytophthora infestans.

$\checkmark$ Wheat head scab is caused by fungi from the genus Fusarium.

$\checkmark$ Tan spot of wheat (caused by Pyrenophora tritici-repentis) is one of the most devastating diseases of wheat.

\section{Symptoms of plant diseases}

Symptoms are visible or otherwise recognizable deviations features of diseases.

A symptom of plant disease is a visible effect of disease on the plant. Symptoms may include a detectable change in colour, shape or function of the plant as it responds to the pathogen. Leaf wilting is a typical symptom of Verticilium wilt, caused by plant pathogens Verticillium alboatrum and $V$. dahliae. Pathogen is not visible, but rather a symptom that is being caused by the pathogen. 
A sign of plant disease is a physical evidence of the pathogen, for example, fungal fruiting bodies are a sign of disease. For instance, on the wheat leaves, fruiting bodies of the fungus Blumeria graminis are clearly visible; or another example - on the ergot of rye, you can see sclerotia - part of the fungus Claviceps purpurea.

Spots and blights (blotches), lesions can be necrotic - death of plant cells or tissues, or the colour of plants has been changed. Typically, if causal agents are viruses - some parts of plants become yellow or other. Spots usually mean quite small, distinctive spots with borders. Spots can become larger and diffuse together, and such symptoms are called blotch. Some diseases cause large spots on leaves or flowers or stems, is called blight.

Cankers. Affected woody plants produce dead, and often sunken, patches on stems and branches. Some cankers may be raised by the production of callus tissue by the plants.

Galls. Swellings or overgrown patches of leaf or stem tissue are commonly known as galls. They may be caused by fungi (like leaf gall), bacteria (such as crown gall), or even insects.

Leaf curl. Deformed and discoloured leaves suffer from leaf curl. Peach leaf curl is caused by a fungus; viruses may also produce such symptoms.

Rots. Soft or discoloured and dying plant tissues generally indicate rot. Fungi and bacteria can cause rot on fruit, stems, flowers, or roots.

Rusts. Orange or yellowish spots, galls, or coatings are caused by rust fungi. Rusts may affect leaves, stems, flowers, or fruits.

Wilts. Drooping leaves and stems indicate the plant does not get enough water. This may be caused by improper watering or by fungi and bacteria that clog the plant's water conducting system. Fungi cause the Fusarium and Verticillium wilt; bacterial wilt is a problem in cucumbers and related crops.

\section{EXERCISE 1}

To become acquainted with the symptoms of fungi and describe them. 


\section{THE COMPOSITION OF FUNGI}

Fungi are a separate group of living organisms - the kingdom Mycota. More than 148000 species of fungi are recognized, and new species are found every year. Fungal cell walls contain chitin and hemicellulose, and during metabolism, urea is produced like in animal metabolism.

Fungi are composed of living filaments called hyphae, which form the mycelium. Each cell of the hyphae has a nucleus, mitochondria, and other organelles.

In many fungi, the cells of the hyphae have cross walls called septa; however, there exist fungi with no septate hyphae. Some of the fungi lack the typical mycelium and exist as amoeboid (plasmodia) - a multinucleate mass of cytoplasm without the typical cell wall, continually changing the shape. The composition of fungi provides a large surface for the absorption of nutrients.

The mycelium can be colourless or white, pink, pale, or dark.

The mycelium can be endophytic, when it develops into the substrate (e.g., into the tissue of plants), or exophytic, when it develops above the substrate. Endophytic mycelium can develop among the cells or into the cells.

\section{Composition of the mycelium}

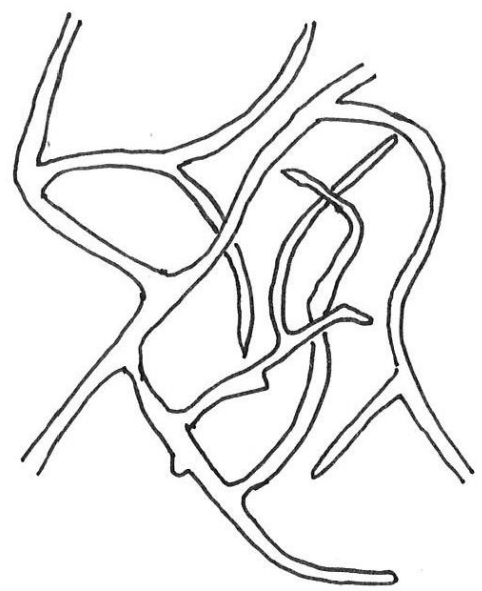

No septate hyphae

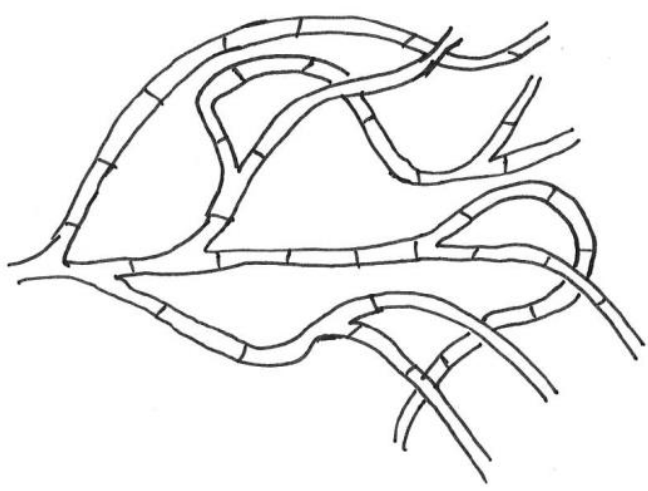

Septate hyphae

The mycelium and a particular hypha can produce special forms, especially under unfavourable conditions. The special forms provide a chance of surviving, a better contact with the substrate, and a more successful take-up of nutrients. Some forms take part in the process of reproduction.

\section{Special forms of a hyphae (some examples)}

Clamp connection - a hyphal branch that connects two adjacent cells - such hyphal bridge allows the nuclei to move into other cells. This kind of mitosis is typical for some Basidiomycota. 
Haustoria - absorbent organs that originate from a hypha and penetrate into a host cell; the shape of a haustorium varies depending on the species.

Appressorium - a flat swelling that forms at the end of a germ tube or a vegetative hypha and that adheres to the surface of the host before penetrating. The shape of appressoria varies depending on the species of fungi.

Rhizoids - tapered, slender, often branched hyphae, superficially similar to a plant root; serve to attach the mycelium to the substrate and also to absorb the nutritive substances.

Stolons - aerial, vegetative running hyphae, unbranched, that connect two groups of rhizoids.

Oidia - small hyphal cells that are derived from the fragmentation of somatic hyphae; behave as asexual spores.

Chlamydospores - thick-walled, resistant spores that are derived from the fragmentation of somatic hyphae; their function is survival.

\section{Special forms of the mycelium (some examples)}

Sclerotia - hardened structures composed of fungal tissue that resists under unfavourable conditions; they can have different shapes and sizes and a firm and thick cortex, frequently chitinized, and are brown or blackish in colour. Sclerotia are capable of germinating and forming fruiting bodies, or reinitiating the vegetative growth.

Mummification of tissues - hardened structures composed of fungal and substrate (often fruits) tissues; their functions are similar to those of sclerotia.

Stromata - a compact mass of hyphae, in which asexual or sexual reproductive organs often develop. Stromata can be hard or soft, coloured in different colours.

Rhizomorph - a thick, resistant mycelial cord, composed of fungal hyphae. Functions of rhizomorphs are like plant root functions, they mainly provide fungal spread and colonization of substrate.

\section{Reproduction of fungi}

Reproduction of fungi occurs via spores or via mycelium (also via special forms of the mycelium).

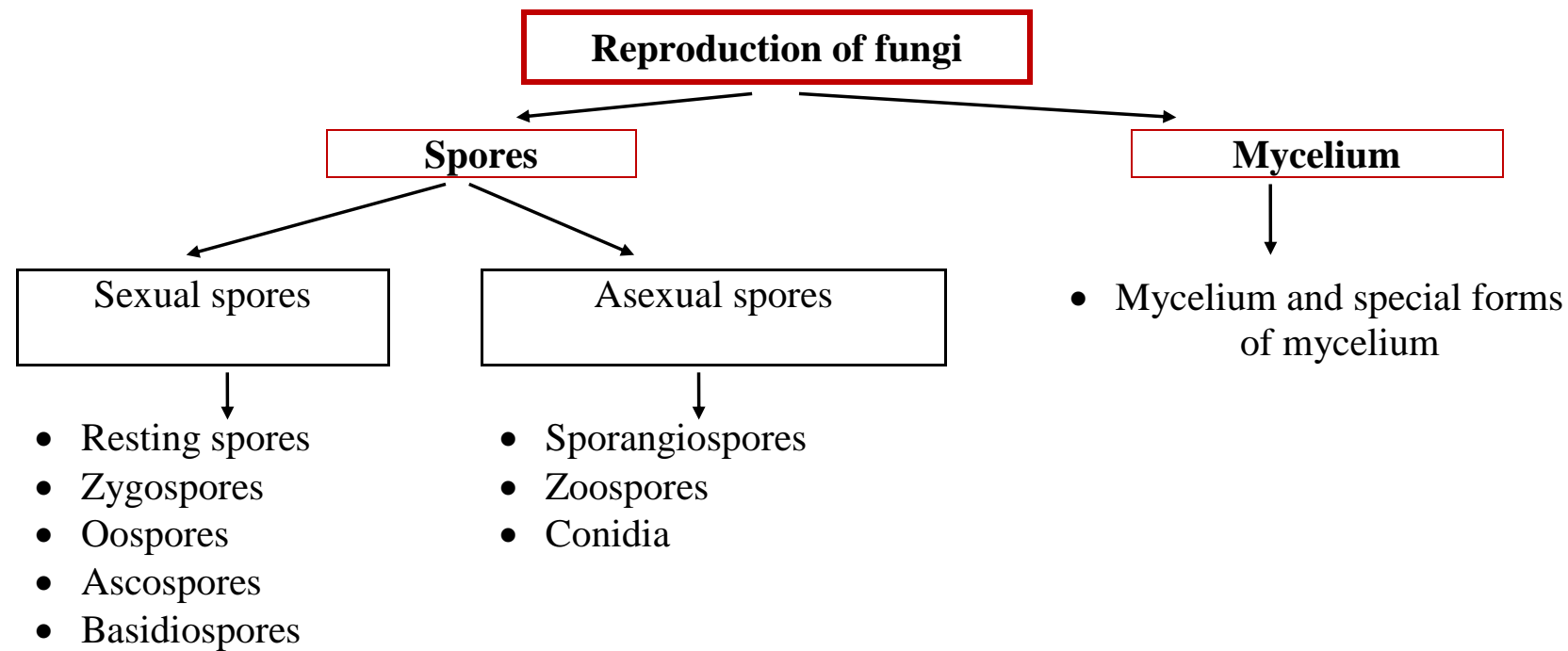


Fungi spread via mycelium during the period of vegetation, and mycelium provides the fungi with the possibility of surviving under unfavourable conditions. In some cases, the mycelium disintegrates into separate cells that accomplish the functions of spores. For example, yeasts (blastospores), moulds (oidia), and fungi from the genus Fusarium (chlamydospores) reproduce in this way.

Asexual reproduction occurs under favourable conditions during the period of vegetation. Asexual reproduction provides rapid spread of fungi. Many asexual generations form during one period of vegetation.

Sexual reproduction often occurs before or after overwintering. The purpose of sexual reproduction is to provide the genetic diversity for a continued ability of the species to adapt to changing conditions.

\section{Morphology and development of the sexual and asexual spores}
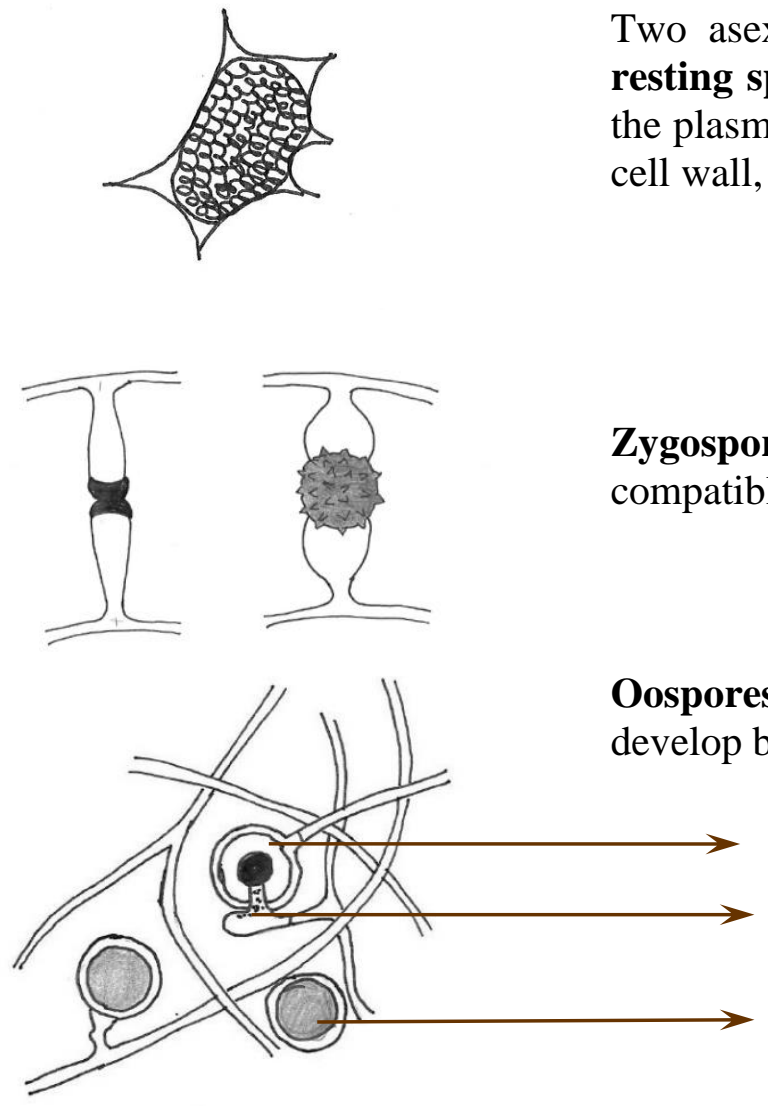

Two asexual spores (zoospores) fuse to form resting spores, or resting spores develop inside the plasmodium. The resting spores have a thick cell wall, and they can survive for a long time.

Zygospores are produced by fusion of two compatible hyphae.

oogonium

antheridium

oospore

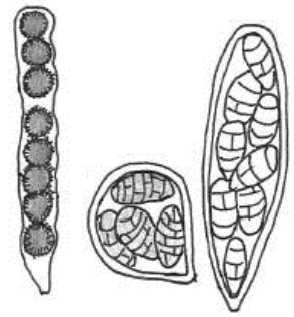

The male structure (antheridium) and the female structure (oogonium) pair up, and after a complicated process, ascospores develop into asci. 

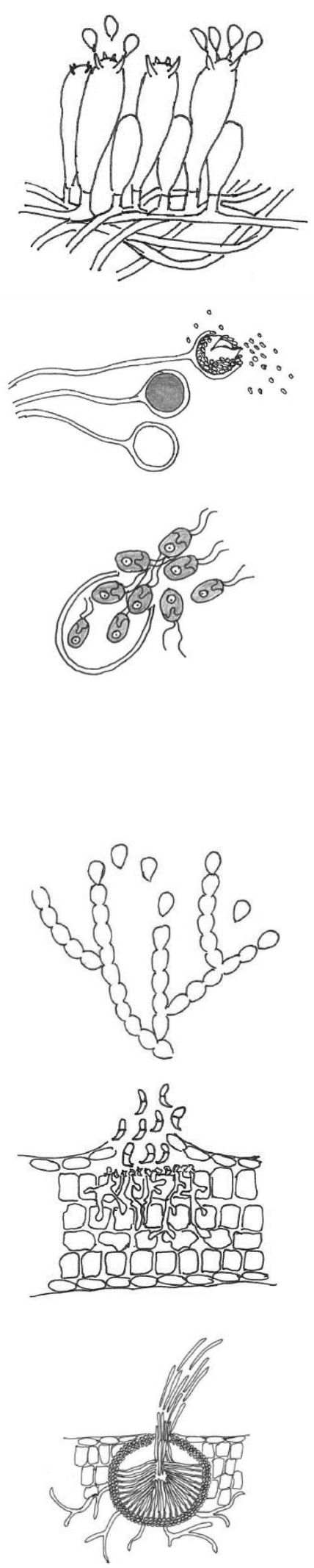

Two haploid nuclei fuse into a specialized cell basidium; basidiospores develop externally on the basidium.

Sporangiospores are asexual, small and airborne; they develop inside the fragile membrane-covered sporangium at the end of a hyphal stalk.

Zoospores are motile, asexual spores with one or two flagella; zoospores develop inside the zoosporangium.

Conidia are asexually produced spores, generally formed at the apex or side of specialized conidiophores:

- conidia are produced on specialized hyphal branches that are not covered with a layer of the fungal or host tissues. Conidiophores can be distributed throughout the fungal colony, or they can be clustered together;

- acervuli - an aggregation of hyphae in a form of a small cushion, which erupts through the epidermis of the host plant;

- pycnidia - a flask-shaped fruiting body inside the host tissues.

\section{EXERCISE 2}

$\checkmark$ To become acquainted with the composition of fungi and special forms of hyphae, and to study the biological importance of these forms.

$\checkmark$ To study the reproduction of fungi, and to understand the biological importance of each type of spore and the differences among the spores. 


\section{THE MAIN PRINCIPLES OF THE SYSTEMATICS OF FUNGI AND OTHER MICROORGANISMS - THE CAUSAL AGENTS OF PLANT DISEASES}

The systematics of living organisms (including fungi) is the arrangement of organisms in a classification system that consists of taxa (sing. taxon) - groups or categories, or any hierarchy within a classification system - from kingdom to species. Other important taxa of fungi are phylum, order, genus, and others.

Earlier, systematics of fungi was based on their morphological features (existence of fruiting bodies and their composition, traits of spores, etc.) and on fungal biology, physiology, and ecology. Rapid development of molecular genetic methods during the last decades allows investigating the genomes of fungi. These methods are used for the identification and systematics of fungi and other organisms. The systematic position of a fungus changes together with novel achievements in science, simultaneously changing also the names of fungi.

The systematics of fungi has a scientific and practical importance. Sometimes, a precise and quick identification of the causal agent is complicated, but it is possible to determine the family or order, or at least the phylum, to which the pathogen belongs. After determining the higher taxa, further identification is easier. If precise identification is too complicated, the knowledge about systematic position of pathogens allows understanding the main biological features of the pathogen, which is necessary for disease management.

The understanding of the place of fungi in the world of living organisms has changed in the course of time. Formerly, fungi were placed among lower plants, but, in reality, they have more similarities with animals. Now, fungi form a special kingdom - MYCOTA (synonym FUNGI).

Plant pathogens from the kingdoms Protozoa and Chromista are discussed together with fungi, because, from a practical point of view, they are similar in composition, reproduction and life cycles and have common ecological niches as well.

Plant pathogens occur in different kingdoms - Mycota, Protozoa, Chromista, Bacteria - and in the group Viruses (viruses are not included in the common systematics of other living organisms).

\section{SYSTEMATICS}

of plant pathogens that belong to Protozoa, Chromista, and Mycota

PROTOZOA

Myxomycota

Plasmodiophoromycota
CHROMISTA

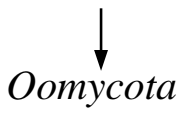

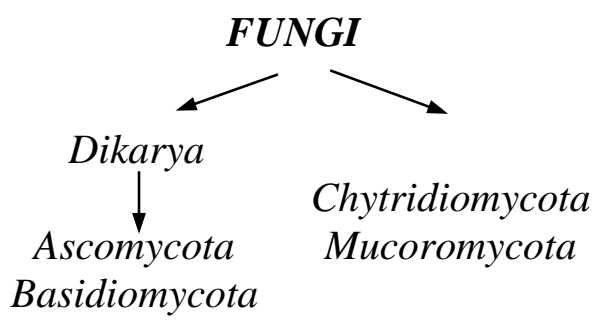


Principles of the formation of fungal taxa names

\begin{tabular}{|c|c|c|}
\hline Taxon & Latin name or its ending & Examples \\
\hline Kingdom & Fungi/Mycota & $\times$ \\
\hline Subkingdom & Dikarya & $\times$ \\
\hline Phylum & -mycota & Ascomycota \\
\hline Subphylum & -mycotina & Dothideomycotina \\
\hline Class & -mycetes & Pleosporomycetidae \\
\hline Subclass & -mycetidae & Pleosporales \\
\hline Order & -ales & Pleosporaceae \\
\hline Family & -aceae & Pyrenophora \\
\hline Genera & $\times$ & Pyrenophora tritici-repentis \\
\hline Species & $\times$ & $\times$ \\
\hline Uncertain placement & Incertae sedis & \\
\hline
\end{tabular}

Many fungi have both sexual and asexual reproduction. Asexual stage is often soon after infection and may be the only stage observed until the end of the season or even until the beginning of the next season. Many fungi have two different names: one for sexual reproduction stage, and the other for asexual stage:

Teleomorph - the sexual (perfect) state of a fungus;

Anamorph - the asexual or so-called imperfect state of a fungus.

Holomorph - the fungus as a total organism in all its forms and phases, including the teleomorph and the anamorph.

The two names have formed historically, because each stage was discovered in different times, often in different regions, and usually by two different authors. Therefore, for a long time, it was not clear whether two fungi are one and the same or not. For this reason, each stage has its own systematic position, which is based on the morphological features.

Essential changes in the systematics (International Code of Nomenclature for algae, fungi, and plants) were done at the International Botanical Congress in 2011, when the main principle "one fungus, one name" was established.

Transition to one name takes place gradually. For that reason, for the time being, different names of fungi are used in different sources of literature (including scientific).

Most often, the name of teleomorph is recognized as holomorph; however, there are exceptions, for example, Botrytis, Fusarium, Zymoseptoria tritici, etc. are names of the anamorph. Exceptions have been made, because these names are much more widespread and anamorph is more important in the life cycle of a fungus. 


\section{Designation of species}

\begin{tabular}{|c|c|c|l|}
\hline Designation & $\begin{array}{c}\text { Its } \\
\text { meaning }\end{array}$ & Example & \multicolumn{1}{|c|}{ Explanation } \\
\hline sp. & species & Alternaria sp. & $\begin{array}{l}\text { Genus is known, but species is } \\
\text { unknown. }\end{array}$ \\
\hline spp. & species & Alternaria spp. & $\begin{array}{l}\text { It is known that there are several } \\
\text { species, but it is not known exactly } \\
\text { which. }\end{array}$ \\
\hline sensu lato (s.l.) & $\begin{array}{c}\text { in the broad } \\
\text { sense }\end{array}$ & $\begin{array}{c}\text { Heterobasidion } \\
\text { annosum } \text { s.l. }\end{array}$ & $\begin{array}{l}\text { In general, it is H. annosum, but } \\
\text { could also be another, very similar } \\
\text { species. }\end{array}$ \\
\hline $\begin{array}{c}\text { sensu stricto } \\
\text { (s.s. or s.str.) }\end{array}$ & $\begin{array}{c}\text { in the strict } \\
\text { sense }\end{array}$ & $\begin{array}{c}\text { Heterobasidion } \\
\text { annosum } \text { s.s. }\end{array}$ & It is exactly H. annosum. \\
\hline
\end{tabular}

The right names of fungal plant pathogens are listed in:

http://www.indexfungorum.org/Names/Names.asp

https://www.mycobank.org/

\section{EXERCISE 3}

$\checkmark$ To understand the basic concepts of the systematics. 


\section{ASCOMYCOTA}

Dikarya (fungi with dikaryotic hyphae, in which cells contain a haploid nucleus from each parent) - include the phyla Ascomycota and Basidiomycota.

The mycelium of Ascomycota is well-developed and branched; the hyphae are septate. Ascomycota are characterized by sexual spores - ascospores, which are produced in asci.

\section{Development of ascospores}

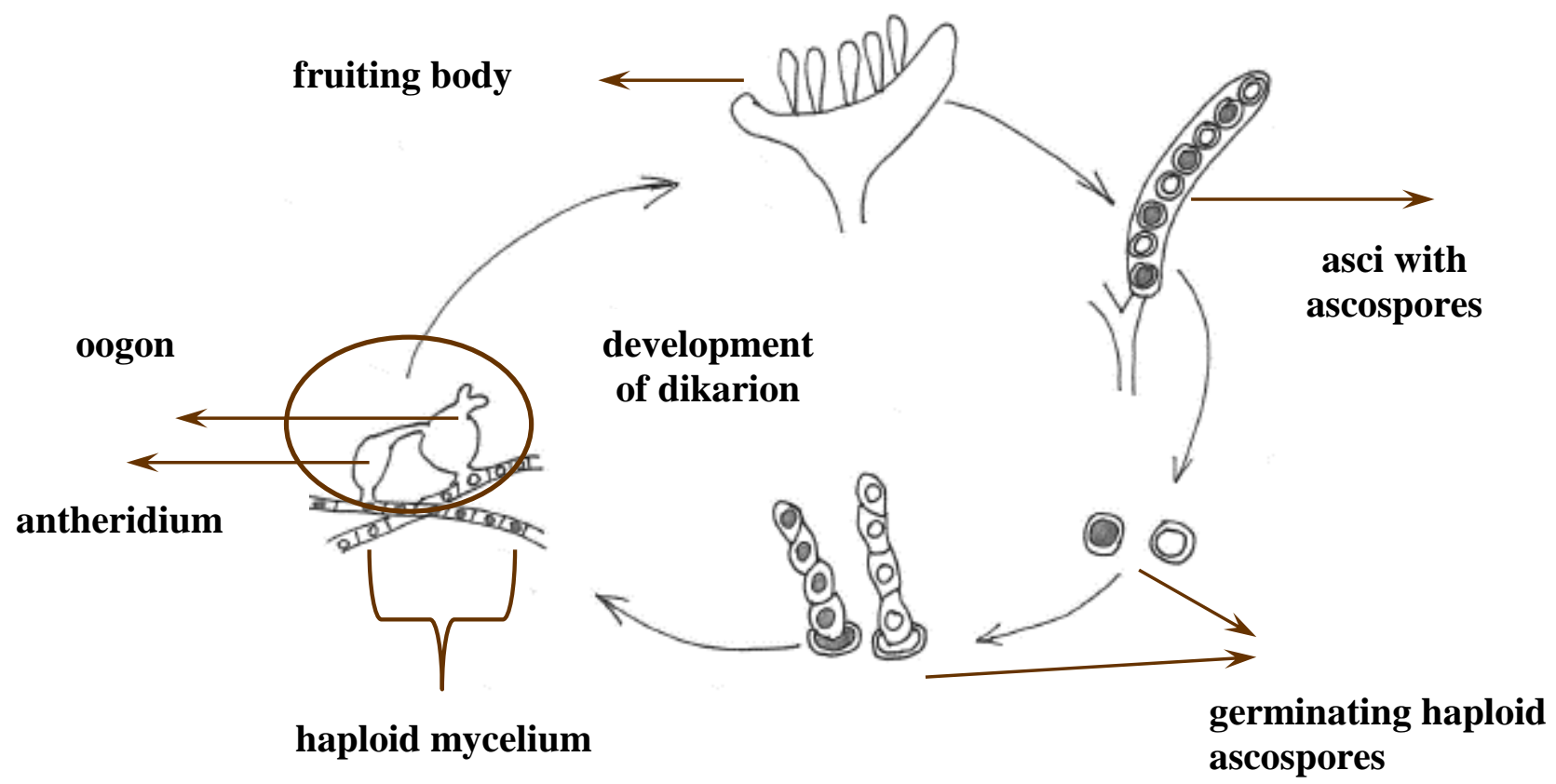

In many cases, fungi from Ascomycota produce conidia. The colour, size, and shape of the conidia along with the type of the fruiting body are used to identify the anamorph stage.

Asci are formed:

$>$ directly on the surface of a leaf or on another plant part;

$>$ inside the fruiting body. The general term for the fruiting body is "ascoma" or "ascocarp"; there are several types of ascocarps.

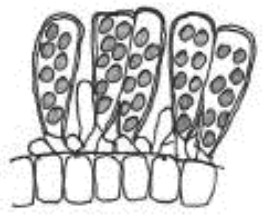

\section{Naked asci are exposed on the surface of infected tissues}




\section{Morphology and composition of the fruiting bodies of Ascomycota}

Cleistothecium (pl. cleistothecia) is a spherical, completely closed fruiting body with no special opening to the outside. The wall of the fruiting body disintegrates at maturity to liberate the ascospores.

Chasmothecium (pl. chasmothecia) is generally spherical, with no natural opening; asci with ascospores are released when a crack develops in the wall of the fruiting body. This type of the fruiting body is unique and is observed only for the fungi from the order Erysiphales, which causes powdery mildew. Formerly, only the term "cleistothecium" was used.

The difference between cleistothecia and chasmothecia is the way the ascospores release actively or passively.

Perithecium (pl. perithecia) is a flask-shaped fruiting body, usually dark, with an opening for spore release.

Apothecium (pl. apothecia) is a fruiting body that opens widely at maturity to expose the hymenium of asci; it commonly assumes the shape of a cup, disk, or saucer, but also other shapes occur.

Pseudothecium (pl. pseudothecia) is a fruiting body very similar in appearance to a perithecium, but differs from it in its mode of development; asci are bitunicate, having a double wall that expands when it takes up water and shoots the enclosed spores out suddenly to disperse them.

\section{Morphology of ascocarps}

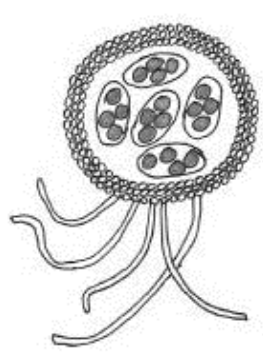

cleistothecium

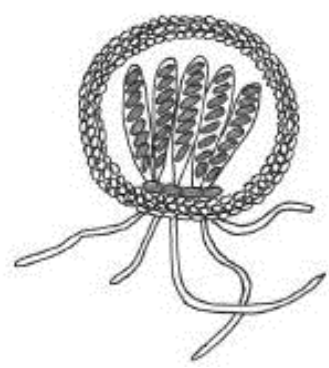

chasmothecium
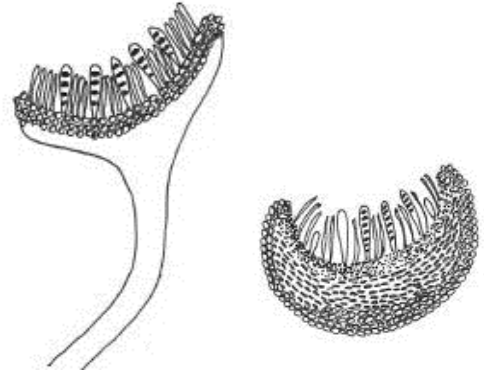

apothecia with and without stalks
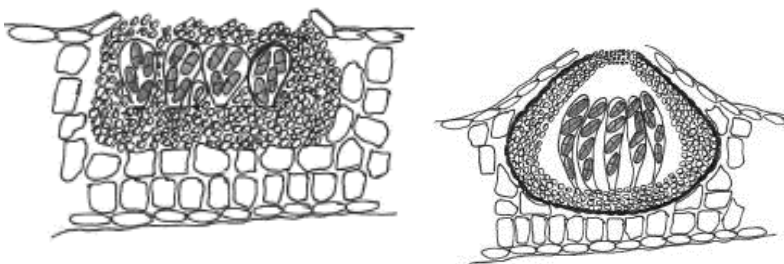

pseudothecia

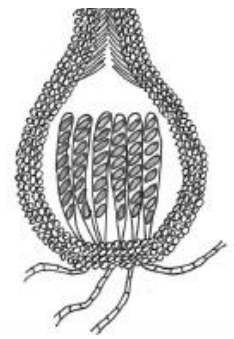

perithecium

\section{EXERCISE 4}

$\checkmark$ To become acquainted with the biological properties of the phylum Ascomycota, and to study the formation and morphology of the fruiting bodies. 


\subsection{IMPORTANT ORDERS FROM THE PHYLUM ASCOMYCOTA THE ORDER TAPHRINALES}

Fungi from the order Taphrinales have well-developed septated mycelium.

Taphrinales develop asci directly on the surface; they do not have fruiting bodies (ascocarps).

Fungi from the genus Taphrina cause different deformations of the infected parts of plants, because they produce biologically active substances that stimulate cells to divide (hyperplasia) and grow larger than normal (hypertrophy), causing swelling and distortion of leaves, fruits, or twigs.

$\diamond \quad$ Taphrina deformans - causes leaf curl of peach and other stone fruits. Infected leaves are severely deformed and often display a variety of colours ranging from light green and yellow to shades of red and purple. Leaves turn brown, shrivel and drop from the tree. Pathogens infect fruits, twigs, and shoots. Asci develop on the surface of infected leaves.

$\diamond \quad$ Taphrina pruni - causes the pocket or bladder plum gall; other species - T. alni and T. padi - infect alder and bird cherry. Developing fruits elongate and are hollow, without stones. Asci develop on the surface of the fruit.

$\diamond$ Taphrina betulina - causes witch's broom on the birch. The result of infection is the development of large numbers of axillary shoots on infected buds. Leaves are pale, smaller than normal, and crisp. Asci develop on the lower surface of leaves.

Witch's brooms can be found on different trees and can be caused by different factors, including fungi, phytoplasma, insects, mites, and also abiotic factors.

\section{Other important orders from the phylum Ascomycota}

- Eurotiales (Penicillium, Aspergillus, and other genera) - form conidia, but cleistothecia form rarely.

- Diaporthales (Gaeumannomyces graminis, Diaporthe and other genera) - develop perithecia and/or conidia.

- Ophiostomatales (Ophiostoma novo-ulmi etc.) - develop conidia and perithecia.

- Fungi from the order Hypocreales form perithecia, but not in all cases. Perithecia are usually placed in stromata, which are pulpy, and brightly coloured. Majority of the genera form conidia as well.

$\diamond \quad$ Neonectria ditissima - causal agent of European canker, which damages deciduous trees.

$\diamond \quad$ Nectria cinnabarina - a saprotroph, infects old or damaged branches of trees.

$\diamond \quad$ Claviceps purpurea - causal agent of the ergot of rye.

$\diamond \quad$ Fusarium spp. - causal agents of different diseases, for example, ear scab, dry rot, wilts, etc.

$\diamond \quad$ Verticillium spp. - causal agents of different plants, including trees.

$\diamond$ Trichoderma spp. - antagonists of other fungi. 
- Orders Pleosporales, Dothideales, and Capnodiales - during the life cycle, usually develop pseudothecia and conidia; however, pseudothecia are not important for all genera.

$\diamond$ Zymoseptoria tritici - causal agent of Septoria leaf blotch.

$\diamond \quad$ Pyrenophora spp. - causal agents of different cereals' blotches.

$\diamond \quad$ Leptosphaeria spp. - causal agents of oilseed rape cancer.

$\diamond \quad$ Venturia spp. - causal agents of apple, pear, olive, and other trees' scab.

$\diamond$ Alternaria spp. - causal agents of different leaf blotches, mould, rot, and also saprotrophs.

- Fungi from the order Helotiales have apothecia and can be with and without stalks; apothecia are dark or brightly coloured. Majority of the genera, but not all, form conidia.

$\diamond$ Sclerotinia sclerotiorum - causal agent of white rot; has an extremely wide specialization.

$\diamond \quad$ Monilinia spp. - causal agents of fruit rots.

$\diamond \quad$ Botrytis spp. - causal agents of grey rot and other diseases, affect different crops and wild plants.

$\diamond \quad$ Oculimacula spp. - causal agents of cereals' eye spot.

- Rhytismatales form dark, seated apothecia, some of genera have conidia.

$\diamond \quad$ Rhytisma spp. - cause tar spot on the leaves of maple and other trees.

$\diamond$ Lophodermium spp. - causal agents of needle cast.

\section{EXERCISE 4.1}

$\checkmark$ To become acquainted with the most important orders from the phylum Ascomycota. 


\subsection{THE ORDER ERYSIPHALES}

The Erysiphales order has only one family - Erysiphaceae. Fungi from Erysiphales are obligate parasites and cause powdery mildew; the typical sign of the disease chasmothecia.

Symptoms of mildew. Infected plants display white powdery spots on leaves and other living parts of plants. Later in the vegetation season, mildew becomes darker and thicker. Mildew develops on the surface of plants and consists of the mycelium (grows above the substrate and forms appressoria), short conidiophores, and conidia. Conidia form one by one or are arranged in chains, depending on the species. Later in the growing season, visible chasmothecia develop into the mycelium; however, they do not develop in all cases.

Powdery mildew spreads via airborne conidia during the vegetation season. Chasmothecia overwinter in plant debris or in living plants; the mycelium rarely survives in the buds or other parts of living plants.

Fungi from Erysiphales have high specialization, they are widespread, and more than 6000 species are known. The powdery mildew of cereals, trees, ornamental plants, fruits, and vegetables is economically important in Latvia.

The systematics of the order Erysiphales has changed significantly during the last years. The names of holomorphs have already been accepted for this order. For the systematics of the Erysiphales fungi, peculiarities of the teleomorph, anamorph and mycelium are being considered.

For example, morphology of the teleomorph of strawberry causal agents corresponds to Sphaerotheca, but, considering the kind of conidia development (in chains), the holomorph is Podosphaera.

Morphological features of chasmothecia are also important:

$>$ form of the appendages of chasmothecia;

$>$ number of asci in one chasmothecium.

\section{Morphology of chasmothecia}

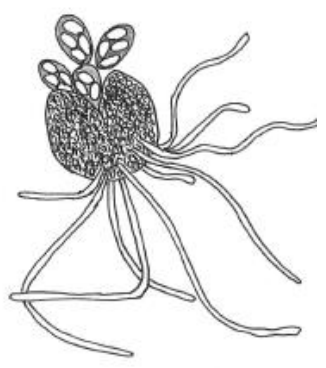

Erysiphe - appendages are simple, short, similar to vegetative hypha. Each chasmothecium contains several asci.

Blumeria - appendages are simple, short, similar to vegetative hypha. Each chasmothecium contains several asci.

The genera Blumeria and Erysiphe have similar chasmothecia, but their mycelia differ and they are parasites in different hosts. The fungi from Blumeria develop secondary mycelium, which is darker and denser; they are parasites of grasses (Gramineae, syn. Poaceae spp.). 

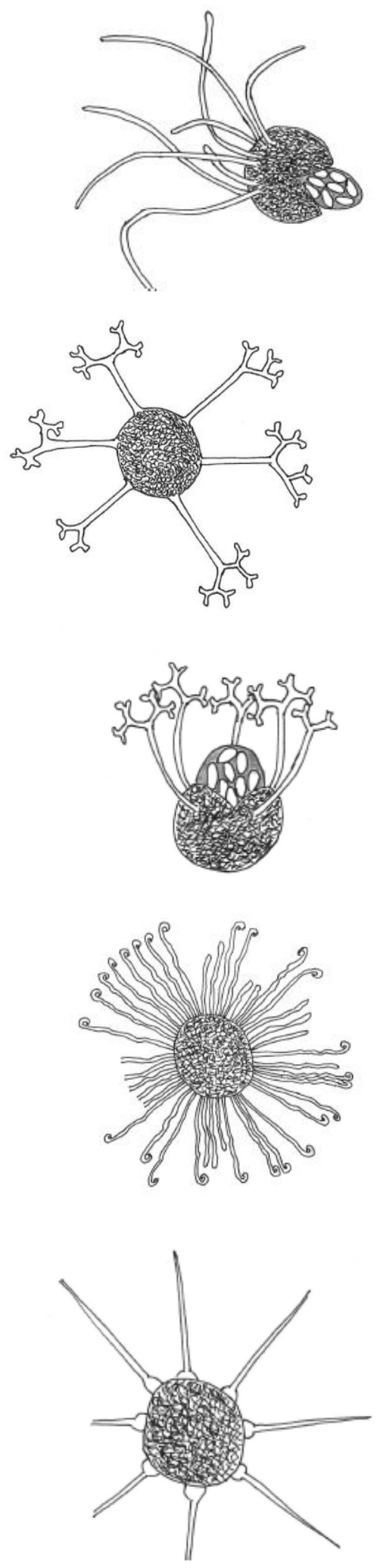

Sphaerotheca - appendages are simple, short, similar to vegetative hypha. Each chasmothecium contains only one ascus.

Microsphaera - appendages are branched more than once; tips are slightly declined. Each chasmothecium contains several asci.

Podosphaera - appendages are long, thin; tips are dichotomously branched more than once. Each chasmothecium contains only one ascus.

Uncinula - appendages have nestled-down tips. Each chasmothecium contains several asci.

Phyllactinia - appendages are long, needle-shaped, straight, globularly expanded at the bottom. Each chasmothecium contains several asci.

\section{EXERCISE 4.2}

$\checkmark$ To become acquainted with the symptoms of mildew.

$\checkmark$ To identify the teleomorph of Erysiphales fungi according to the morphology of the appendages of chasmothecia and the number of asci in each chasmothecium. 


\section{TRAITS OF ASEXUAL REPRODUCTION OF FUNGI FROM THE PHYLA ASCOMYCOTA AND BASIDIOMYCOTA}

Many anamorphs of fungi have originated artificially by linking up genetically distinctive fungi:

1) fungi which sexual stage is unknown (or may not even exist);

2) fungi that have lost their sexual stage during evolution;

3) asexual stages of Ascomycota and Basidiomycota.

Deuteromycetes have been excluded from the systematics as a separate group since 2011, because molecular genetic analyses prove that $\sim 90 \%$ of these fungi are Ascomycota, others are Basidiomycota, or their belonging is not known.

Development features of conidia, and morphological traits of conidiophores and conidia are important traits for fungal identification. Conidiophores can be placed: directly on the substrate, in the acervuli (stroma), or in the pycnidia.

\section{Location of conidiophores}
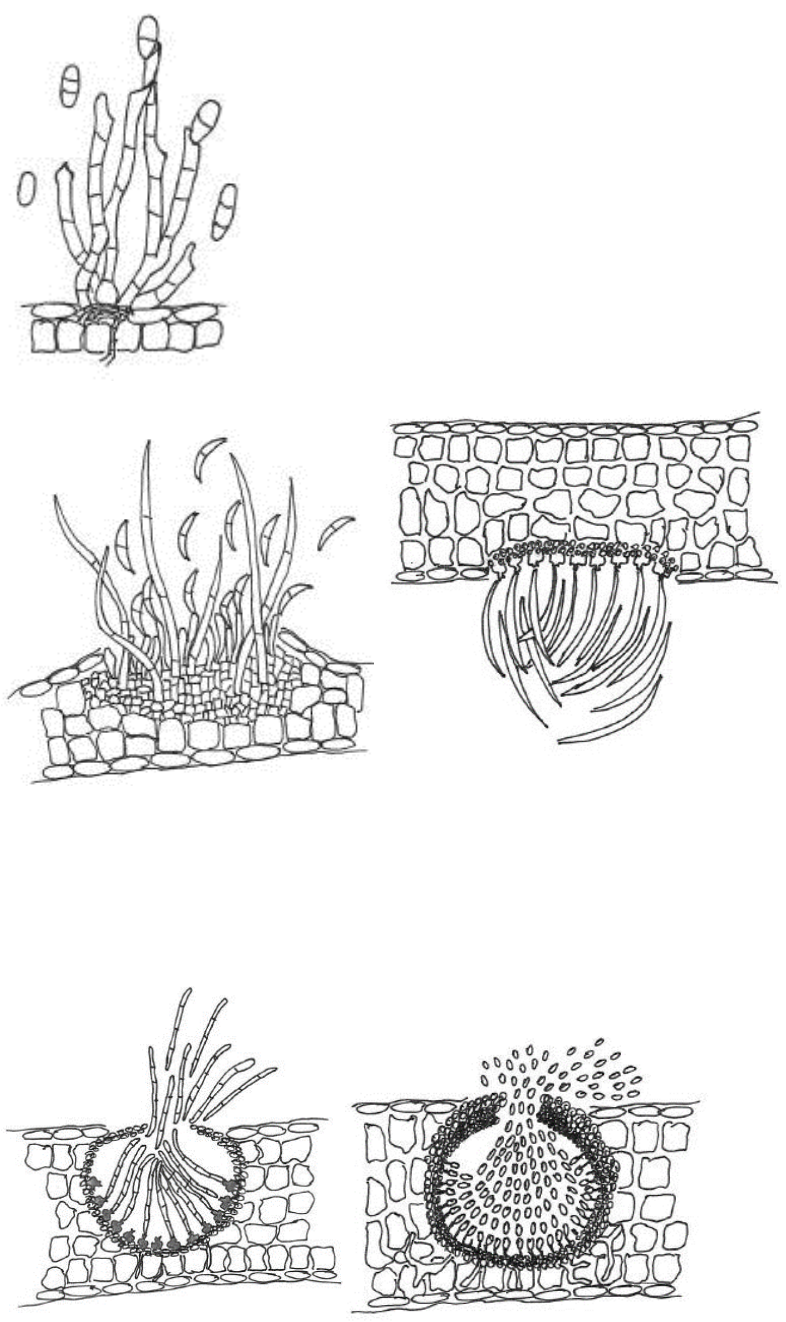

Mould - conidiophores are produced directly on the substrate, they can be short or long, branched or not branched (Alternaria spp., Fusarium spp., Botrytis spp.).

Acervuli - an aggregation of hyphae in the form of a small cushion, which is formed by short, crowded conidiophores; sometimes sterile structures (paraphyses) are between the conidiophores. Acervuli can be covered by epidermis or develop on the surface of epidermis.

Below epidermis, for example, Diplocarpon rosae develops.

On the surface of epidermis, for example, Blumeriella jaapii develops.

Pycnidia - generally spherical or flaskshaped cavities lined with conidiophores (for example, Zymoseptoria tritici, Leptosphaeria spp.). 
Conidia can be transparent, light or dark, one-cell or multicellular; their shapes can be various as well: round, oblong, curved, etc. In the multicellular conidia, septa can be longitudinal and transverse.

\section{Morphology of conidia}
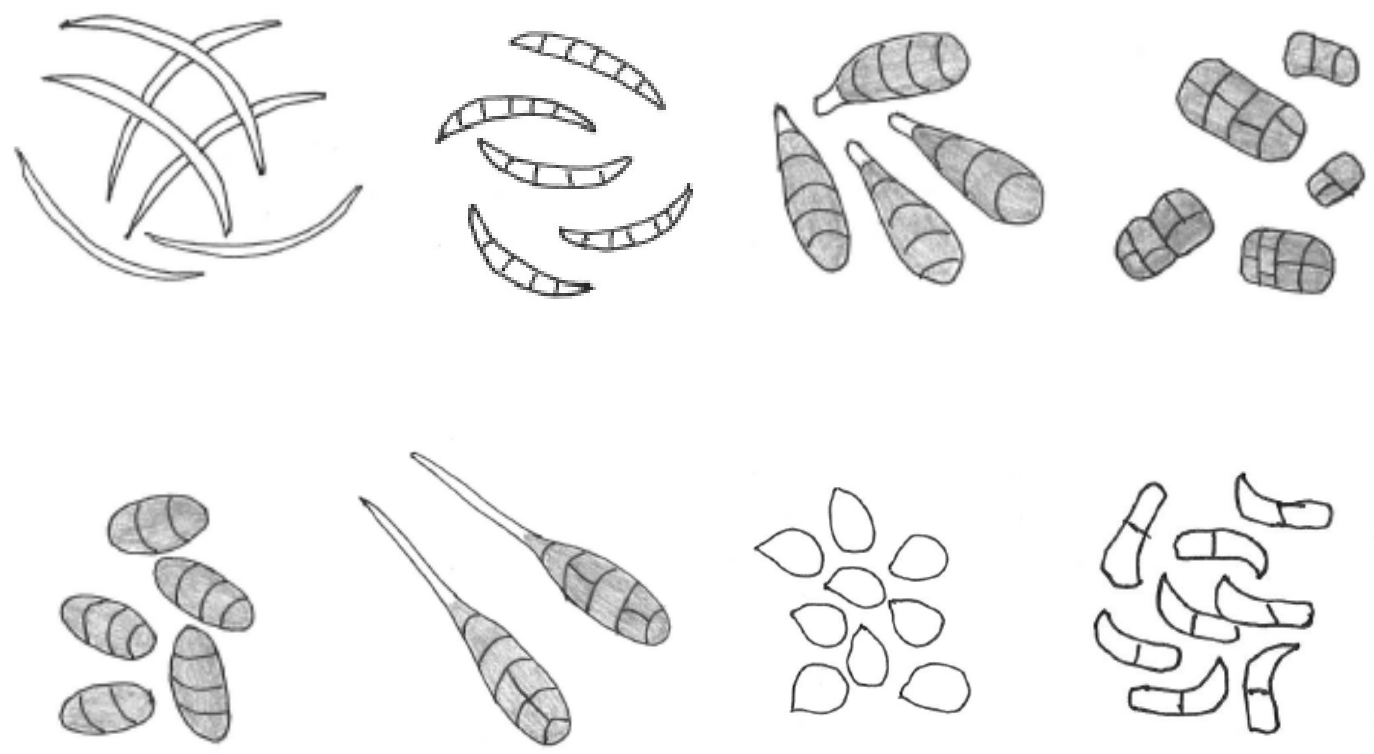

\section{EXERCISE 5}

$\checkmark$ To become acquainted with the symptoms of diseases.

$\checkmark$ To describe the location and morphology of conidia.

\section{An example of description}

\begin{tabular}{|l|l|l|l|}
\hline \multicolumn{1}{|c|}{$\begin{array}{c}\text { Symptoms of } \\
\text { disease }\end{array}$} & \multicolumn{1}{c|}{$\begin{array}{c}\text { Location of } \\
\text { conidia }\end{array}$} & Shape of conidia & Drawing \\
\hline $\begin{array}{l}\text { Necrotic blotches on } \\
\text { the leaves of cereals, } \\
\text { with small, black } \\
\text { dots. }\end{array}$ & Pycnidia & $\begin{array}{l}\text { Multicellular, } \\
\text { oblong }\end{array}$ & \\
\hline
\end{tabular}




\section{BASIDIOMYCOTA}

This phylum includes fungi that are morphologically different; however, all of them produce fruiting bodies - basidia with external basidiospores. Mushrooms, puffballs, conks, other fungi with visible fruiting bodies, and some important plant pathogens belong to the phylum Basidiomycota.

Life cycles of fungi vary depending on the genus; however, most basidiomycetes are dikaryotic for most of their life. They have a pair of haploid nuclei in each cell.

Sexual process begins when two haploid hyphae fuse to form dikaryotic hyphae - the dominant state in most basidiomycetes. Two haploid nuclei fuse in a basidium.

In most cases, the basidiospores germinate to form haploid hyphae, which must fuse with sexually compatible hyphae to form the dikaryotic mycelium or spores.

\section{Development of basidiospores}

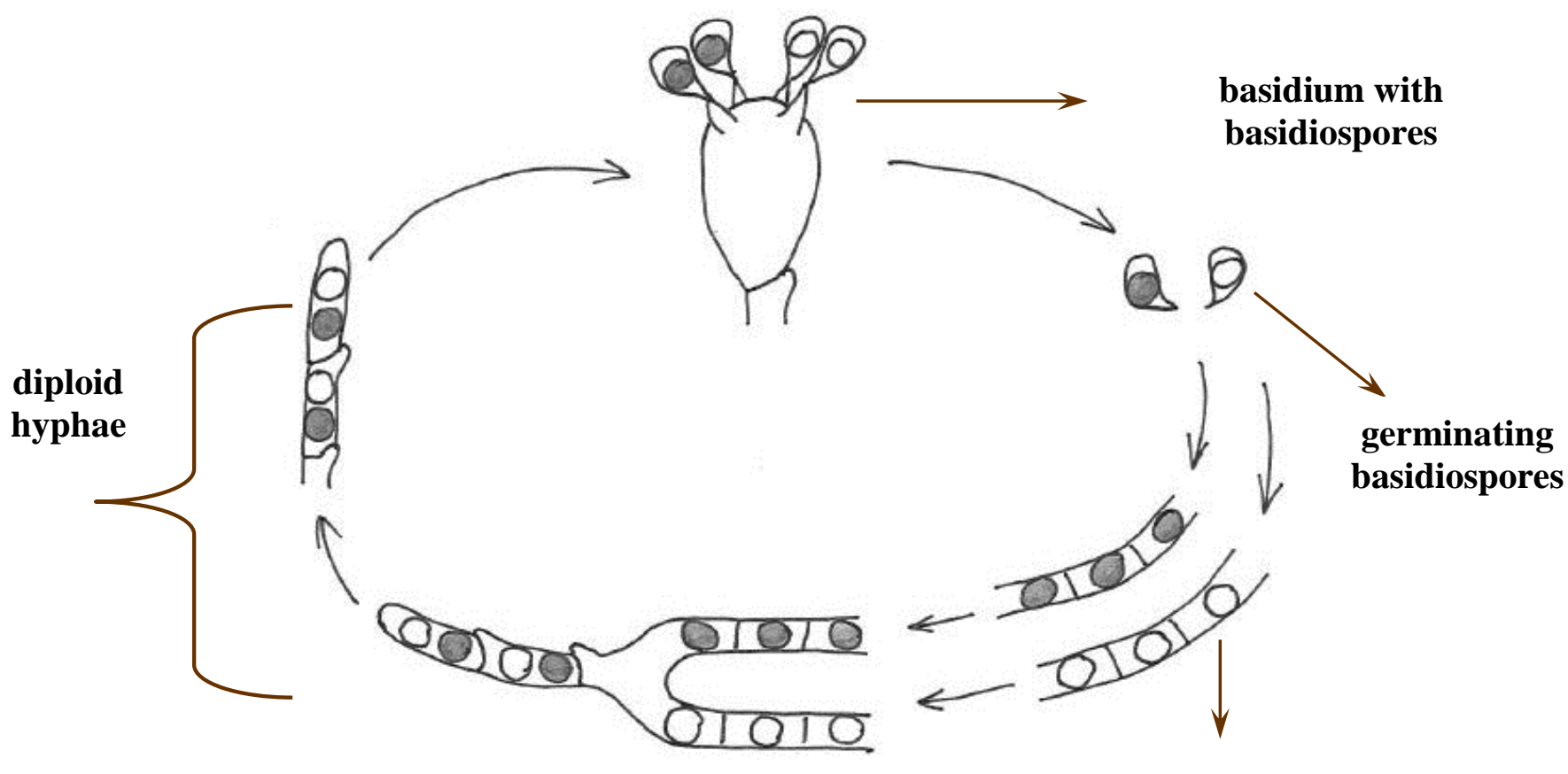

haploid hyphae

\section{Subphyla of Basidiomycota}

Ustilaginomycotina

Pucciniomycotina

Agaricomycotina
More than 1700 species; cause mainly smuts and bunts of cereals.

More than 8000 species ( $8 \%$ of all described fungi); most of them cause rusts of different plants.

More than 20000 species; include mushrooms, bracket (shelf) fungi, coral fungi, puffballs, earthstars, stinkhorns, etc. 


\subsection{THE ORDER USTILAGINALES}

Ustilaginales is the most important order. There are also some other pathogens which belong to this subphylum.

Exobasidiales are obligatory pathogenic fungi, which induce formation of galls on the leaves of Ericaceae (cranberry, blueberry, rhododendron, etc.). The pathogen causes hypertrophy of tissues; basidia form under epidermis, directly on the mycelium.

Fungi from the order Ustilaginales are causal agents of diseases called smut. More than 1200 species are determined as members of Ustilaginales. Most of them infect ears of grass, but there also exist species that damage leaves, flowers, and other parts of plants.

Bunt, caused by Tilletia caries, is a harmful disease of wheat in Latvia. The causal agent of the disease survives as teliospores (dust-like, dark, thick-walled) on grains. Teliospores germinate together with grains and infect the sprouts. Symptoms of the disease are not visible; the first symptoms appear after flowering at the stage of milk ripeness. Sori (a spore mass under a cover) form instead of some grains, but other parts of ears are not damaged.

Loose smut damages mostly barley and wheat. The disease is caused by fungi from the genus Ustilago. Most frequently, Ustilago nuda (host barley) and Ustilago tritici (host wheat) are observed. All parts of ears are damaged (except central axis), and, instead of grains, a mass of dark, very small spores is formed under a transparent coat. At spore maturity (the time of cereal flowering), the coat breaks and the spores are blown onto open flowers, and, afterwards, the ovaries are infected. After germination, the fungi invade the developing embryo in the seed. The fungus stays alive in the seed until the next growing season, when the fungus grows together with the plant. Infected grains do not visibly differ from the healthy grains.

Urocystis occulta causes stripe smut of rye and other grasses. The fungus damages vegetative parts of plants - stems and leaves. Diseased plants are stunted, producing excessive numbers of tillers, and, at the stage of heading, long grey-black streaks develop between veins on leaf blades and sheath, where teliospores form.

\section{$\underline{\text { Exercise 6.1 }}$}

$\checkmark$ To become acquainted with the symptoms of smuts, and to study the life cycles of smuts. 


\subsection{THE ORDER PUCCINIALES}

Fungi from the order Pucciniales cause diseases called rusts. More than 5000 species of rust fungi are described. Rusts damage cereals, many ornamental plants, trees, and shrubs. Causal agents of rusts are highly specialized - each species or race can infect only specific species or only some varieties of plants.

Life cycles of the causal agents of rusts are complicated, with up to five separate spore stages. Some of the fungi have only two or four stages of spores; there are fungi that can develop either with a full life cycle (all five stages of spores) or with an incomplete life cycle (certain spore stages are missing). Some of these fungi are heteroecious, requiring two unrelated host plants, but some are monoecious - they develop on the same plant.

\section{A full life cycle of the dioecious rust fungus}

Survival spores are teliospores, which germinate and produce a basidium with basidiospores.

Basidiospores infect the alternate host and form spermatia (synonym - pycnia); pycnia fuse and form a dikaryotic mycelium. From this mycelium, dikaryotic aeciospores are produced in aecia. Aecia are usually easy visible and have different forms: goblet- or cup-shaped, galls or pustules. Aecia are mostly yellow or orange. Aeciospores infect the host.

After infection, pustules of powdery, brightly coloured urediniospores are produced. The urediniospores are the repeating stage, they re-infect the host, and many generations of urediniospores develop on the host. Later in the season, the mycelium produces telia, in which black teliospores are formed. Teliospores have a thick cell wall; they are the survival stage of the fungus. Teliospores are aggregated in pustules or in crust-like forms.

The morphology and deposition of teliospores are used to identify the genera of Pucciniales.

\section{Morphology and deposition of teliospores}

Pucciniaceae - teliospores have stalks, and they aggregate in pustules.

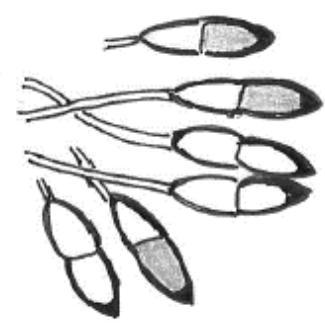

Puccinia - teliospores are two-celled, with medium-long stalks.

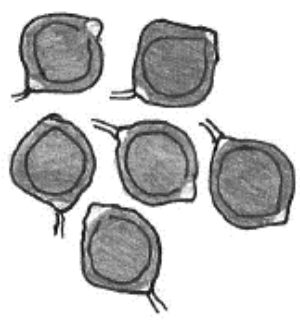

Uromyces - teliospores are one-celled, with short stalks. 

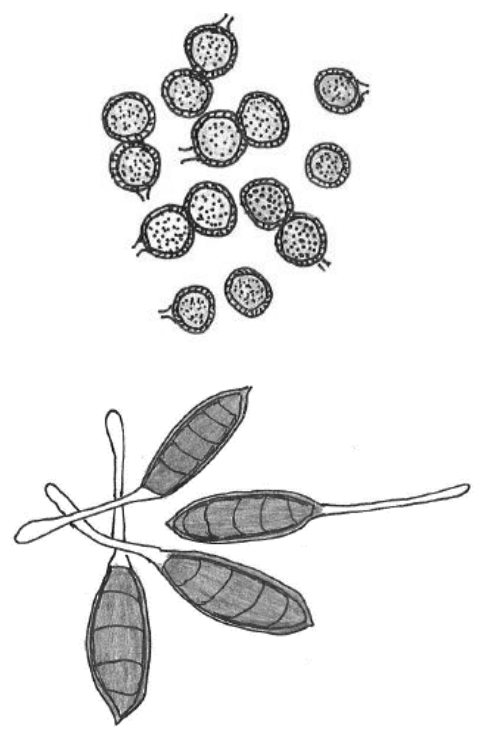

Tranzschelia - teliospores are twocelled, deeply constricted at the septum, with cells sometimes separating.

Phragmidium - teliospores have many septa and long stalks.

Melampsoraceae - teliospores have no stalks, and they aggregate in a crust-like form or in columns.

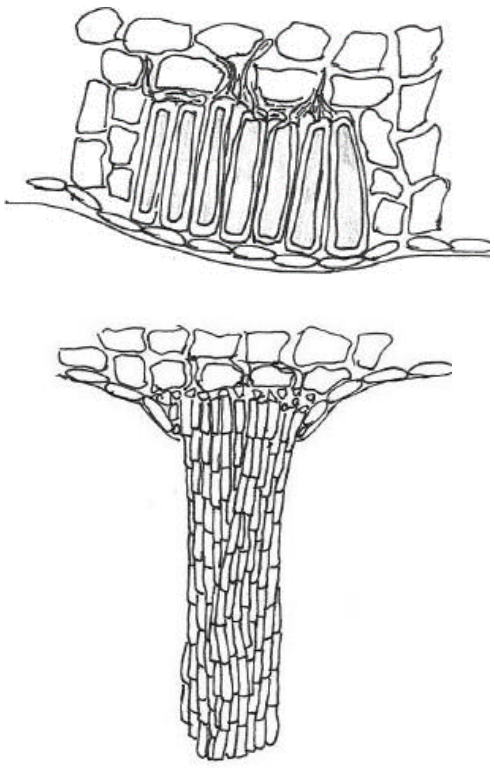

Melampsora - teliospores aggregate in a crust-like form.

Cronartium - teliospores form hair-like columns.

\section{EXERCISE 6.2}

$\checkmark$ To become acquainted with the symptoms of rusts, and to study the life cycles of rusts.

$\checkmark$ To identify the genera of Pucciniales according to the deposition and morphology of the teliospores of Pucciniales. 


\subsection{AGARICOMYCOTINA}

The subphylum Agaricomycotina includes fungi from different ecological niches: destructors of organic matter, mycorrhizal fungi, pathogens of plants, and pathogens of other living organisms.

Bracket fungi (shelf fungi, conks) are an important group of fungi, which cause destruction of woods and wood remains. They decompose lignin and cellulose. This process is called decaying. The fruiting bodies develop outside the substrate (living wood, necrotic wood, or processed wood).

Fruiting bodies can be standing or resupinate, annual or perennial. Consistence of the fruiting body can be leathery, woody, corky, etc.

\section{Different types of the Agaricomycotina fruiting bodies}

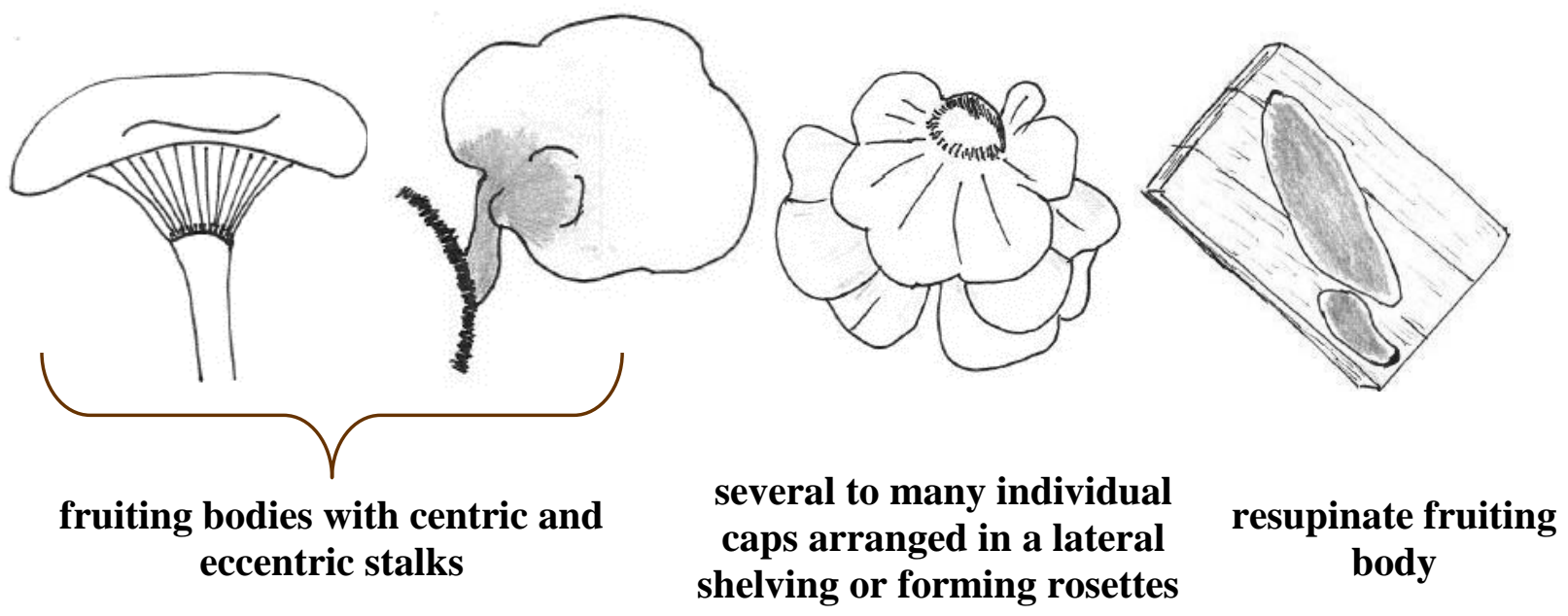

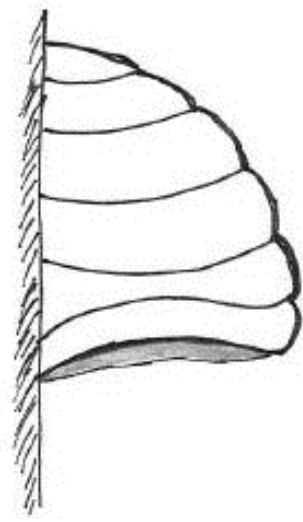

shelf-like

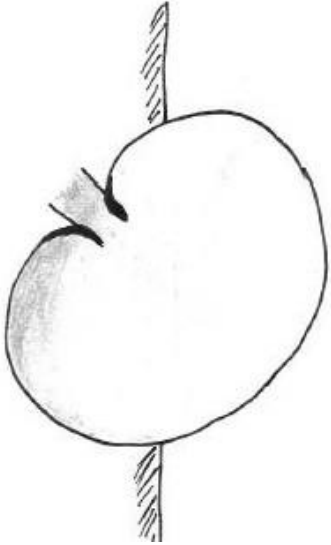

kidney-shaped

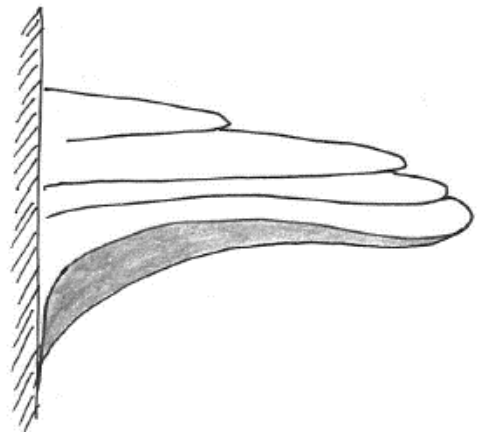

flat fruiting body 
Basidiospores form in the hymenium (a layer of cells specialized for the production of spores), which is located in the fruiting body. Between basidia, cystidia - large, somatic cells - are located, but their importance is unknown.

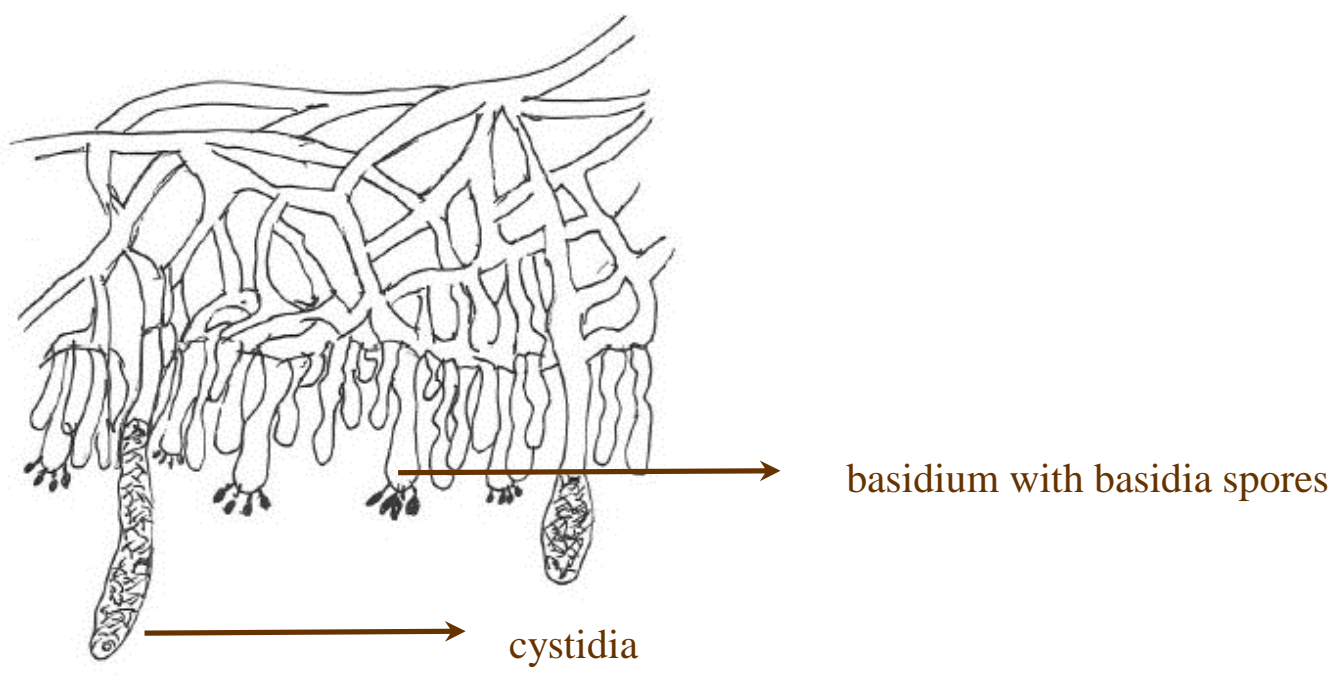

Hymenium can be gills, tubes, spines, lamellae, etc.

\section{More prevalent types of hymenium}

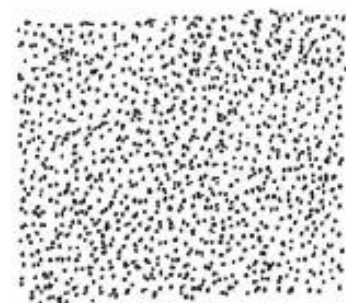

pores

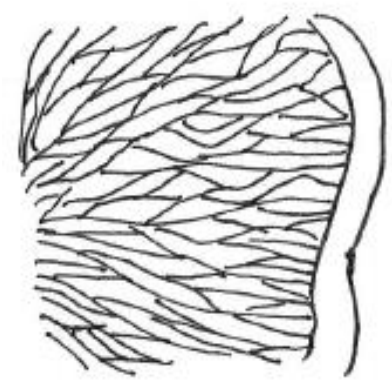

labyrinthic

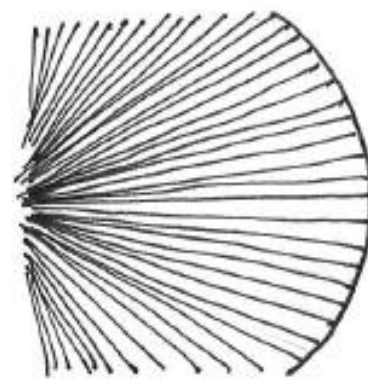

gills (lamella)

\section{Other important orders and examples}

\section{Agaricales}

$\diamond$ Armillaria spp. (honey fungi) - saprotrophs on the stumps, causal agents of white root rot of conifers and other plants.

$\diamond \quad$ Pleurotus spp. (oyster mushrooms) - saprotrophs on the dead wood.

$\diamond$ Agaricus spp. - saprotrophs; there are hundreds of species, including the edible mushroom A. campestris.

$\diamond \quad$ Amanita spp. - contain several hundreds of species, including some of the most toxic mushrooms.

$\diamond \quad$ Lycoperdon spp. (puffballs).

$\diamond \quad$ Typhula spp. - pathogens of cereals, causal agents of grey snow mould. Unlike other Agaricales, Typhula spp. form sclerotia during their life cycle. 


\section{Russulales}

$\diamond$ Heterobasidion spp. - wide-spread causal agents of root rot, infect coniferous trees, more rarely also other trees.

$\diamond \quad$ Russula spp. - there are several hundreds of species; mycorrhizal fungi, some species are edible.

\section{Boletales}

$\diamond \quad$ Boletus spp. - mycorrhizal fungi, one of the most valuable edible fungi.

$\diamond \quad$ Coniophora spp. - causal agents of wood rot, for example, C. puteana is a destructor of wood.

$\diamond \quad$ Serpula spp. - causal agents of wood rot, for example, S. lacrymans is one of the most destructive indoor wood pathogens.

\section{Cantharellales}

$\diamond \quad$ Cantharellus spp. - mycorrhizal fungi, including the edible fungus $C$. cibarius.

$\diamond \quad$ Rhizoctonia solani - an important plant pathogen, causal agent of different diseases: seedling damping-off, potato black scarf, black mould, etc.

\section{Polyporales}

$\diamond \quad$ Fomitopsis spp. - causal agents of stem brown heart rot, for example, F. pinicola.

$\diamond \quad$ Laetiporus spp. - causal agents of stem rot, for example, L. sulphureus.

$\diamond \quad$ Ganoderma spp. - wood decay fungi, live on the living, but most often dead, trees, for example, Ganoderma applanatum.

\section{Hymenochaetales}

$\diamond \quad$ Inonotus spp. - causal agents of stem rots, for example, I. obliquus.

$\diamond \quad$ Phelinus spp. - one of the most destructive causal agents of stem rot, infect living trees, for example, $P$. chrysoloma.

\section{Phallares}

$\diamond \quad$ Phallus spp. - stinkhorns, for example, P. impudicus.

\section{EXERCISE 6.3}

$\checkmark$ To become acquainted with the morphological features of fungi from the subphylum Agaricomycotina and their ecological niches. 


\section{MUCOROMYCOTA and CHYTRIDIOMYCOTA}

\section{MUCOROMYCOTA}

Majority of fungi from the subphylum Mucoromycotina are saprotrophs or weak pathogens.

The mycelium is well developed, but hyphae are nonseptate. Zygospores (sexual) and sporangiospores (asexual) are typical for this group of fungi.

Fungi from the order Mucorales cause moulds of seeds (including seeds of trees and shrubs), stored fruits, vegetables, food products, etc.

The most important genera-Mucor and Rhizopus.

Fungi from the subphylum Glomeromycotina form mycorrhiza; the most important genus is Glomus.

Fungi from the subphylum Entomophthoromycotina are parasites of insects. The most important genus is Entomophthora, which infects aphids, flies, and other insects. These fungi are used in biological plant protection.

\section{CHYTRIDIOMYCOTA}

Majority of species of the phylum Chytridiomycota are saprotrophic organisms, but plant pathogens are obligate parasites. The vegetative body of the fungus is a naked single-cell plasmodium or a primordium-type mycelium. The fungi reproduce zoospores with one flagellum and survive as resting spores.

\section{The most important causal agents of plant diseases}

Olpidiaster brassicae causes death of cabbage seedlings. This disease affects seedlings of cabbage at different stages of their development. Crown rot becomes black and decays, turgor of plants decreases, and seedlings turn yellow and wilt. The pathogens survive via resting spores, but spread via zoospores. Resting spores germinate and form zoospores under favourable conditions.

Synchytrium endobioticum causes the wart of potatoes - a disease subject to quarantine. Warty, cauliflower-like outgrowths develop on tubers, stolon, and roots, rarely on lower leaves of potatoes. Initially, the warts are white; afterwards, they darken and decay. The shape and size of outgrowths vary, they can be bigger than potato tubers. The pathogens spread via zoospores and survive via resting spores.

\section{EXERCISE 7}

$\checkmark$ To become acquainted with the morphology, reproduction and development of Mucoromycota, and to know the most important genera.

$\checkmark$ To become acquainted with the morphology and biological features of fungi from the phylum Chytridiomycota, and to learn the symptoms caused by this group of fungi. 


\section{CHROMISTA}

Cell walls of microorganisms from the kingdom Chromista contain cellulose; they have various enzymes, and also their metabolic processes are different.

Pathogens of plants belong to the phylum Oomycota. The mycelium of pathogens from Oomycota is well structured, branched, but its hyphae are non-septate. The pathogens have sexual (oospores) and asexual (zoospores and conidia) reproduction. They produce sporangia on specialized branched (tree-like) hyphal structures. Some Oomycota have an ability to produce zoospores or germinate directly as single spores, depending on environmental conditions; single spores are sometimes called conidia.

The pathogens overwinter as oospores or as a mycelium in plant residues. The development of plant diseases caused by Oomycota depends on moisture, because asexual spores are able to germinate only in a drop of water.

Plant pathogens belong to three orders: Saprolegniales, Albuginales, and Peronosporales.

Organisms from the order Saprolegniales are mostly saprotrophic organisms in water or in moist soils. Aphanomyces cochlioides is a plant pathogen that causes damping-off of seedlings.

Pathogens from the order Albuginales are obligate parasites, for example, Albugo candida causes white rust or blister rust of cruciferous, including horseradish. They develop mycelium in the tissues of plants and have haustoria to absorb nutrient elements from plant cells.

Asexual spores develop on the short conidiophores and form pustules, initially under the epidermis; at the maturity of spores, the epidermis breaks and white pustules appear on the infected parts of plants.

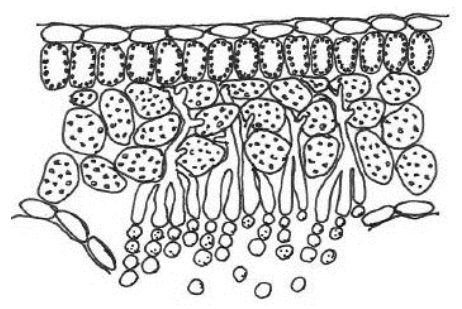




\subsection{THE ORDER PERONOSPORALES}

The order Peronosporales contains several genera, to which important plant pathogens belong. Some of the genera can be identified based on the morphology of sporophores.

\section{Morphology of sporophores from the Peronosporales microorganisms}
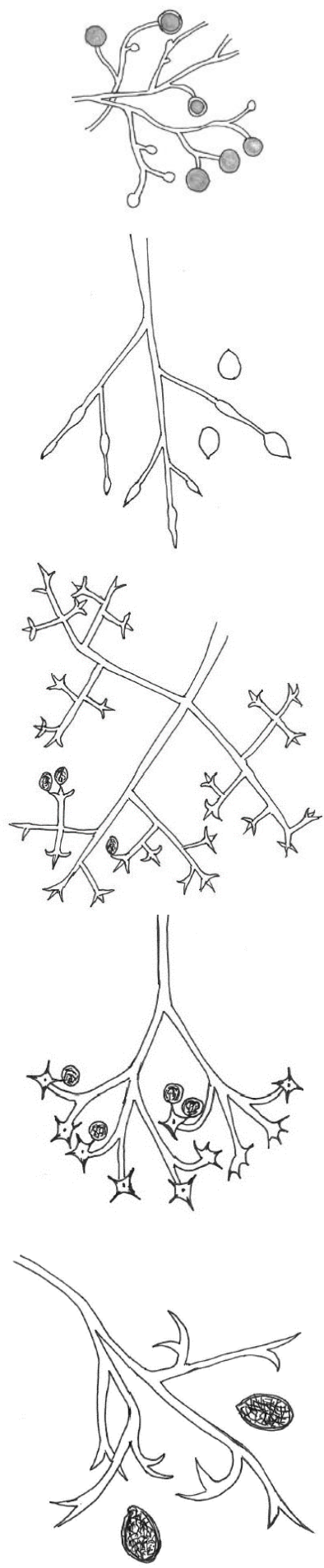

Genus Pythium. Sporangiophores develop on unspecialized or weakly specialized hyphae.

Genus Phytophthora. Sporangiophores are single-branched with a rounded tip.

Genus Plasmopara. Tips of sporangiophores have three branches that form a right angle.

Genus Bremia. Tips of sporangiophores are expanded and have 2-8 denticles.

Genus Peronospora. Tips of conidiophores are sharp and declined. 
The genus Pythium includes several dozens of species; most of them are plant pathogens, but some - pathogens of animals. Pythium spp. usually have wide specialization, survive in the residues of plants, and mostly infect weak plants. A significant stage of the life cycle is the formation of oospores, but spreading happens via zoospores. The mycelium develops into or above the substrate, haustoria are not formed. Sporangiophores form on unspecialized hyphae (they look like other hyphae) or on weakly specialized hyphae.

$\diamond$ Globisporangium debaryanum (formerly Pythium debaryanum) causes damping-off of seedlings of different plants: peas, beets, seedlings of trees, and others.

The genus Phytophthora is one of the biologically and economically devastating genera; several species cause significant yield losses and are harmful for ecosystems.

Until now, 170 species have been described, but it is considered that there are at least 100 more species that have not been identified and described yet.

During their life cycle, Phytophthora spp. can produce oospores, conidia, zoospores, and chlamydospores.

$\diamond \quad$ Phytophthora infestans causes late blight of potatoes and tomatoes. The first symptoms are mostly observed on leaves, in certain cases - also on stems. Water-soaked brown lesions develop on the top side of leaves, and $P$. infestans produces sporangiophores. This sporulation results in a visible grey growth at the leading edge of lesions of the lower surfaces of leaves or stems. The spores are dispersed by water drops to other leaves, other plants, and other fields. The spores are washed into the soil by rain splash, and there they can infect tubers. Pathogens survive in tubers or plant residues; in certain cases, oospores are formed, which survive in the soil or plant residues.

$\diamond \quad$ Other species of Phytophthora cause wilt and/or dieback of different trees, root rots, and blights.

\section{Plasmopara spp., Peronospora spp., Bremia spp., Pseudoperonospora spp., Hyaloperonospora spp., etc. cause downy mildews.}

Downy mildews commonly affect young green leaves, shoots, and even fruits.

Free moisture on the leaves, high relative air moisture and moderate temperature are favourable conditions for the development of downy mildews. They can cause severe yield losses in short periods of time.

The main symptoms of downy mildew are yellow or pale spots on the upper side of a leaf and white sporulation on the lower side of a leaf. The mycelium is well developed; it develops into the tissues of plants. The nutrients are absorbed by haustoria. Conidia, zoospores and sporangia are mentioned in different sources of literature. All mentioned kinds of spores are possible, which depends on the species of pathogens and the weather conditions.

During vegetation period, several generations of asexual spores are produced and pathogens survive as oospores.

Morphology of sporophores differs from that of vegetative hyphae - they are double branched.

\section{EXERCISE 8}

$\checkmark \quad$ To become acquainted with the symptoms of seedling damping-off and downy mildew.

$\checkmark$ To identify the genus of the order Peronosporales, considering the morphology of sporophores. 


\section{PROTOZOA}

Unicellular organisms whose vegetative body is a multinucleate mass of cytoplasm without cell wall called a plasmodium belong to the kingdom Protozoa.

Myxomycota (called slime moulds) is an important phylum of Protozoa. They are saprotrophic organisms living mostly on different residues of plants.

The phylum Plasmodiophorida (formerly Plasmodiophoromycota) has economic importance, because some harmful plant pathogens belong to this phylum.

The organisms from Plasmodiophorida produce asexual spores with two flagella (zoospores). Zoospores penetrate the cells of plants; secondary zoospores form inside the tissue and infect adjacent cells of plants. The plasmodium develops inside the plants; at maturity, the plasmodium becomes a mass of resting spores (spores with thick cell walls) that are being released from the plant tissues as it decays. The resting spores germinate and produce zoospores.

Most significant pathogens:

$\diamond \quad$ Plasmodiophora brassicae - causes clubroot of cruciferous plants. Pathogen survives in the soil with resting spores. Resting spores germinate, form zoospores, and infect roots of cabbage or other cruciferous. Products of pathogen's metabolism cause rapid growth and fission of the host's cells, and, as a result, galls are forming on the roots;

$\diamond \quad$ Spongospora subterranea - causes powdery scab of potato tubers.

\section{EXERCISE 9}

$\checkmark$ To become acquainted with the morphological and biological features of Protozoa, and to learn the symptoms caused by these pathogens. 


\section{THE PRACTICAL TEST}

\section{THE TASK OF THE WORK}

To diagnose diseases of plants according to their symptoms, and to identify their causal agents depending on their reproduction organs! Student notes and sources of literature can be used.

The level of identification (phylum, order, genus) depends on the symptoms visible on the sample and on the presence of reproduction organs in the pathogen.

* If aecia (spores of causal agents of rust) are observed on a sample, identification of the pathogen is not possible; therefore, only the phylum and the order should be indicated.

* If only conidial stage of Ascomycota is observed on a sample, identification is possible only to the level of the phylum; however, a precise description of conidia and their disposition (mould, acervuli, or pycnidia) as well as a drawing are required.

* If chasmothecia are observed on a sample, identification of the teleomorph of Ascomycota is possible.

\begin{tabular}{|c|l|l|l|l|}
\hline $\begin{array}{c}\text { No. of a } \\
\text { sample }\end{array}$ & \multicolumn{1}{|c|}{$\begin{array}{c}\text { Description of } \\
\text { symptoms }\end{array}$} & $\begin{array}{c}\text { Name of the } \\
\text { disease }\end{array}$ & $\begin{array}{l}\text { Description and } \\
\text { a picture of } \\
\text { reproductive } \\
\text { organs }\end{array}$ & $\begin{array}{l}\text { Pathogen and } \\
\text { its systematic } \\
\text { position* }\end{array}$ \\
\hline $\begin{array}{c}\text { Sample } \\
\text { No. 1 }\end{array}$ & $\begin{array}{l}\text { White mould on } \\
\text { leaves; small dark } \\
\text { balls are visible }\end{array}$ & Mildew & $\begin{array}{l}\text { Appendages of } \\
\text { chasmothecia } \\
\text { have nestled- } \\
\text { down tips }\end{array}$ & $\begin{array}{l}\text { Phylum: } \\
\text { Ascomycota } \\
\text { Order: } \\
\text { Erysiphales } \\
\text { Genus: }\end{array}$ \\
\hline
\end{tabular}




\section{REFERENCES}

1. Agrios G.N. (2005) Plant Pathology, 5th edition, Elsevier, 922 p.

2. Alexopoulos C.J., Mims C.W., Blackwell M. (1996) Introductory mycology, 4th edition, John Wiley\&Sons, $869 \mathrm{p}$.

3. Augu slimības. (2003) B. Bankinas red. Jelgava, LLU, 247 lpp.

4. Bankina B., Bimšteine G. (2014) Praktikums vispārējā augu patologijiā, Jelgava, LLU, 28 lpp.

5. Bankina B., Bimšteine G. (2014) Exercises in basic plant pathology, Jelgava, LLU, 27 p.

6. Barnett H.L., Hunter B.B. (2003) Illustrated Genera of Imperfect Fungi. APS Press, 215 p.

7. Eglītis M. (1938) Augu slimības. Zemnieka Domas, 447 lpp.

8. Glawe A. (2008) The powdery mildews: a review of the world's most familiar (yet poorly known) plant pathogens. Annual Review of Phytopathology, Vol. 46, p. $27-51$.

9. Heffer V., Johnson K.B., Powelson M.L., Shishkoff N. (2006) Identification of powdery mildew fungi. The Plant Health Instructor.

10. Hibbert et al. (2007) A higher-level phylogenetic classification of the Fungi. Mycological Research, Vol. 111 (5), p. 509-547.

11. Miezīte O. (2017) Meža aizsardzība. 2. daḷa. Meža fitopatologija. Jelgava, studentu biedrība "Šalkone", 175 lpp.

12. Rossman A. Y. (2014) Lessons learned from moving to one scientific name for fungi. IMA Fungus, Vol. 5(1), p. 81-89.

13. Schumann G.L., D’Arcy C.J. (2006) Essential Plant Pathology. APS Press, 336 p.

14. Tronsmo A.M., Collinge D.B., Djurle A., Munk L., Yuen J., Tronsmo A. (2020) Plant Pathology and Plant Diseases. CABI, 438 p.

15. Ulloa M., Hanlin T. (2002) Ilustrated Dictionary of Mycology. APS PRESS, p. 447.

16. Webster J., Weber R.W.S. (2007) Introduction to Fungi. Cambridge University Press, 839 p.

17. http://tolweb.org/Fungi/2377

18. http://tolweb.org/Stramenopiles/2380

19. https://microbiologysociety.org/why-microbiology-matters/what-ismicrobiology/protozoa.html

20. https://www.efpp.net

21. http://www.ima-mycology.org

22. https://www.bspp.org.uk 